\title{
New technologies promise to improve blood supply safety
}

\begin{abstract}
NEW YORK - Ever since scientists first linked an obscure blood-borne virus to chronic fatigue syndrome two years ago, blood centers around the world have been scrambling to determine whether their collections are safe. With memories of previous blood scares still fresh in the minds of blood bank officials, many collection centers have even gone so far as to bar donations from people with the disease. But it's not just xenotropic murine leukemia virus-related virus (XMRV) that threatens global blood supplies today. Even well-known pathogens such as hepatitis B virus can slip through the cracks of existing screening techniques, leading to contaminated blood products and accidental infections.

Newly implemented technologies might change all that. Speaking at the New York Academy of Sciences here in late March, a panel of blood bank officials and infectious disease experts unveiled plans to make blood supplies
\end{abstract}

safer by introducing DNA-based screening tests to improve disease detection.

"Our blood supply is safer than it's ever been," Gail Moskowitz, a healthcare consultant who has directed several blood banks in the New York area, said at the 29 March meeting. "But transfusion is still associated with [a] risk of transmission."

In most blood banks across the developed world, each unit of blood is screened for a panel of infectious agents, including HIV, hepatitis $B$ and $C$ viruses, leukemia-associated human T-lymphotrophic virus and the syphiliscausing bacterium. Existing serological assays reveal most pathogens in the blood supply. Yet many of the commonly used tests rely on finding antibodies or pathogens circulating in people's blood and can fail in rare cases when recently infected donors have not yet mounted large immune responses or when viral counts remain low.

\section{Bangladesh eyes the generic pharma pie}

China and India, in 2001 and 2005, respectively, amended their patent laws to comply with the World Trade Organization's Trade Related Intellectual Property Rights (TRIPS) agreement, which bans making generic copies of drugs still under patent protection. The move sparked concerns about the affordability of medicines in poor countries. But Bangladesh, categorized among the world's least developed countries (LDCs) according to the UN, hopes to fill the void - at least for the next five years.

Under the TRIPS agreement, LDCs can make generic versions of patented drugs until 2016. Bangladesh already has an estimated 350 drug companies, from small domestics to large multinationals, which produce $97 \%$ of its domestic demand for medicines. However, to make these medicines for domestic use and export, Bangladesh imports $80 \%$ of the active pharmaceutical ingredients (APIs), the chemicals responsible for a drug's action. "That is a weakness, as the imports do not make our pharma industry a fully integrated one," Abdul Muktadir, secretary general of the Dhaka-based Bangladesh Association of Pharmaceutical Industries, told Nature Medicine.
That could change. In April, Muktadir told an international conference on globalization of pharmaceutical industry in Dhaka that Bangladesh's \$31 million API Park in Munshiganj is scheduled to be completed by July 2012. It's a welcome announcement: government red tape and delays in land acquisition have impeded work on the API Park by almost a decade.

The API Park is designed to be a hub for the raw materials needed to make drugs and is planned to house 40 firms that would make 800 to 1,000 types of generic drugs.

Muktadir said five firms have already been cleared by drug regulatory authorities of some developed countries, paving the way for forays into those markets, and are geared to open up in API Park.

The opening of the site could help improve Bangladesh's position in the pharmaceutical market, according to experts. The country is currently hampered by a lagging focus on drug research and production quality, which could improve through technology transfer after the Park comes up, says Mohammad Sayedur Rahman, a pharmacology expert at Bangabandhu Sheikh Mujib Medical University in Dhaka.

T V Padma

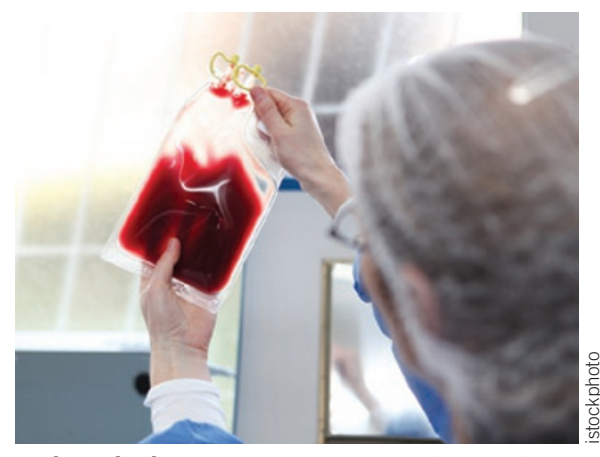

A closer look: Pathogens can go undetected.

Aiming to boost pathogen detection rates, over the past decade or so blood banks in the US have introduced new PCR-based techniques that can pick up minute levels of HIV and hepatitis viral RNA in the bloodstream-and the approach seems to have paid off. Reporting in February, a team led by Susan Stramer, executive scientific officer of the American Red Cross in Gaithersburg, Maryland, found that, among close to 4 million blood samples analyzed, a DNA-based assay was more effective than conventional tests at detecting these three viruses in newly infected donors, including those previously vaccinated against hepatitis B (N. Engl. J. Med. 364, 236-247, 2011). Looking beyond HIV and hepatitis, at the March meeting Stramer also reported the results of a 5,000-donor study from Puerto Rico demonstrating that a similar genetic test was ten times more sensitive in detecting Dengue virus than conventional blood assays.

It's not just viruses that pose a problem, either. The parasites responsible for malaria and babesiosis remain serious safety concerns, but as yet no lab test is licensed to screen blood for the protozoans that cause either disease. Also at the meeting, Sanjai Kumar, who heads the Laboratory of Emerging Pathogens at the US Food and Drug Administration in Rockville, Maryland, reported unpublished data showing that DNA-based tests for both diseases can identify as few as two parasites per milliliter of blood-a detection rate greater than 1,000 times more sensitive than conventional microscopy-based testing.

Yet, even though genetic testing is making the blood supply safer, Stramer notes that price remains an obstacle to implementing the advanced screening techniques. "We are in a technology stranglehold," she says. "Even if a technology can be developed, who is going to pay for it? Hospitals don't want to pay more for blood." 